\title{
SOIL MAPPING TO ASSESS WORKABILITY IN CENTRAL ITALY AS CLIMATE CHANGE ADAPTATION TECHNIQUE
}

\author{
SERVADIO P. ${ }^{1}$ \\ BERGONZOLI S. ${ }^{2, *}$ \\ TODERI M. ${ }^{3}$
}

\author{
${ }^{1,2}$ Consiglio per la ricerca e la sperimentazione in agricoltura \\ [Unità di ricerca per l'ingegneria agraria] \\ [Agricultural Engineering Research Unit], Rome Italy \\ ${ }^{3}$ Marche Polytechnic University. \\ Department of Environmental and Crop Sciences, \\ Ancona, Italy
}

Received: 06/12/13

Accepted: 08/01/14

Available online: 10/01/2014

*to whom all correspondence should be addressed: e-mail: simone.bergonzoli@entecra.it

\section{ABSTRACT}

In this paper soil conventional tillage (CT) in two adiacent on-farm sites, hilly and plain fields, was carried out in comparison with direct-seeding + fertilizing at very low water content. The quality and quantity of work were evaluated through machine performance, fossil-fuel energy requirements and carbon dioxide emissions from agricultural machinery. The fields were previously sampled and mapped to investigate spatial variability of soil properties, to find soil quality indicators and to asses soil workability. The results revealed good traction performance during CT operations (slip values were lower than 15\%). During plowing, time efficiency of the wheeled tractor was 40\% lower with respect to the tracked tractor. Global energy employed was of the same magnitude for the tracked and wheeled tractor $\left(220 \mathrm{kWh} \mathrm{ha}^{-1}\right)$ while was significantly lower $\left(52 \mathrm{kWh} \mathrm{ha}^{-1}\right)$ for direct-seeding+fertilizing. The degree of crushing of the soil caused by CT required further energy employed ( $98 \mathrm{kWh} \mathrm{ha}^{-1}$ ) to seedbed preparation. Fossil-fuel energy requirements from agricultural machinery were significantly lower during directseeding+fertilizing $\left(0.52 \mathrm{GJ} \mathrm{ha}^{-1}\right)$ with respect to the conventional soil tillage $\left(2.30 \mathrm{GJ} \mathrm{ha}^{-1}\right)$. Wheat yield of direct seeded field and the total cost of the crop cycle ( $€ /$ ha) were $9 \%$ and $16 \%$ lower respectively than the values recorded on fields under conventional tillage.

Keywords: soil mapping; GPS; GIS; soil tillage; direct-seeding; energy requirement; $\mathrm{CO}_{2}$ emission.

\section{Introduction}

Soil tillage represents the most influential manipulation of soil physical properties because of repetitive application, its depth range extending up to tens of centimeter and because it influences the type of residue management applied. The need of sustainable agriculture and the increased cost of fuel in tillage operations forced farmers to change the farming methods (Yalcin and Cakir, 2006). In fact, many studies have been done to compare tillage practices, particularly tillage versus no-tillage (NT). Conventional tillage may accelerate mineralization of organic matter, reduce soil fertility, increase water consumption, and deteriorate chemical and physical properties of soil (Chen et al., 2007). On the contrary minimum-tillage and no-tillage, characterized by minimal soil disturbance (Paremelee et al., 1990), may be a good choice for land preparation because it has potential benefits including reduced production costs, saving in fuel, equipment and labor (Allmaras and Dowdy, 1985) as well as soil conservation (Uri, 1997), furthermore direct seeding may be an efficient technology to replace 
transplanting because it is simple and labor-saving (Wu et al., 2005). Improvements in the design of minimum and no-till drills, lower cost and more effective herbicides, a better understanding of the role of tillage in crop production systems, and an increased emphasis on residue management have been key factors in the successful shift to direct seeding (Fowler, 1995), that have slowly become an accepted alternative to conventional tillage systems (Collins and Fowler, 1996). According to Yalcin and Cakir (2006) no-tillage seems to result one of the most sustainable soil management systems, because it reduces labour requirements and machinery costs, fossil-fuel inputs, and soil erosion, while it increases available plant nutrients, soil organic matter content, soil quality, and improves the global environment.

The major surces of GHG fluxes associated with crop production are soil $\mathrm{N}_{2} \mathrm{O}$ emissions, soil $\mathrm{CO}_{2}$ and methane $\left(\mathrm{CH}_{4}\right)$ fluxes, and $\mathrm{CO}_{2}$ emission associated with agricultural inputs and farm equipment operation (Adler et al., 2007).

Loss of soil organic carbon (SOC) under conventional tillage have been extensively documented (West and Post, 2002; Conant et al., 2007), on the contrary conservation tillage practices (minimum and no tillage) may play a leading role in sequestering $\mathrm{CO}_{2}$ achieving a mitigation effect of $\mathrm{CC}$. In fact NT farming is recommended to conserve soil and water but its potential to sequester SOC varies widely due to complex interactions among climate, soil type, crop rotation, duration and management factors (VandenBygaart et al., 2002; Puget and Lal, 2005). Long-term ( $>10 \mathrm{yr}$ ) of NT practices have also the potential to reduce greenhouse gas emissions in humid climates (Chatterjee and Lal, 2009).

The objectives of this study were: 1) to investigate spatial variability of soil properties, to found soil quality indicators and to asses soil workability 2) to investigate the machine performance, the fossil-fuel energy requirements and the $\mathrm{CO}_{2}$ emissions from agricultural machinery in summer soil tillage operations both on hilly and plain field carried out at very low water content, compared with directseeding.

\section{Materials and methods}

The study was conducted in Central Italy in two adjacent on-farm sites on a hilly (178 m.a.s.l.),

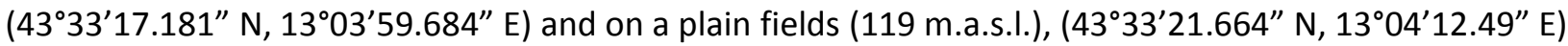
on a silty clay soil seeded with common wheat (Triticum aestivum).

\subsection{Sampling test and mapping}

\subsubsection{Physical and Chemicals soil parameters}

In order to assess the soil workability, two adiacent on-farm sites, an hilly (1.1 ha) and a plain field ( 1 ha) were selected for field tests. Geo-referenced sampling tests based on a grid of $50 \times 50 \mathrm{~m}$ for each field were carried out investigating some soil physical properties from 0 to $0.20 \mathrm{~m}$ depth (Fig. 1). To produce interpolated maps and to describe spatial variability of soil properties the software ArcGIS and the spatial analyst tool natural neighbor (Servadio et al., 2010; Servadio et al., 2011; Servadio and Bergonzoli, 2013) were used. Detected physical-mechanical soil parameters were: particle size distribution, shear strength (SS), dry bulk density (DBd), water content (WC), field capacity (Fc) and structural stability of soil aggregates (Sssa). Soil shear strength was measured using a field inspection vane tester from 0 to $260 \mathrm{kPa}$ (Eijkelkamp). In each field ten shear strength readings were taken in increments of $0.05 \mathrm{~m}$ to a depth of $0.20 \mathrm{~m}$. Dry bulk density was measured by taking ten samples of soil using a corer sampling ring of $100 \mathrm{~cm}^{3}$ of volume at $0-0.20 \mathrm{~m}$ depth. Soil water content at the time of field tests was measured from 0 to $0.20 \mathrm{~m}$ depth by taking samples of soil that were weighed and dried until they reached a constant weight. Soil field capacity was determined using the pressure plate extractor.Structural stability of soil aggregates was determined on the $0.25 \mathrm{~mm}$ fraction through the method of Kemper (1965).

Total organic carbon (C) was determined with the wet oxidation method (Walkley and Black, 1934), organic matter content $(\mathrm{OM})$ was derived from the total organic carbon $(C \times 1.72)$ and cation exchange capacity (CEC) by the barium chloride ( $\mathrm{BaCl} 2$ )-triethanolamine (TEA) method. Exchangeable bases 
[sodium ( $\mathrm{Na})$ ], was determined using $1 \mathrm{M}$ ammonium acetate $\left(\mathrm{NH}_{4} \mathrm{OAc}\right)$ solution (soil/solution ratio 1:10, shaking time $30 \mathrm{~min})$, available phosphate $\left(\mathrm{P}_{2} \mathrm{O}_{5}\right)$ was determined with the Olsen method, colloid index $(\mathrm{Ci})$, a parameter used to evaluate colloid behavior, was calculated as follows:

$\mathrm{Ci}=10 \mathrm{X}_{1}+\mathrm{X}_{2}$

Where: $X_{1}$ is organic-matter content (\%) and $X_{2}$ is clay content (\%), (Beni et al., 2012). During the overall experimentation time, (2011 and 2012), meteorological data (monthly rainfall, minimum and maximum temperatures) were also recorded.

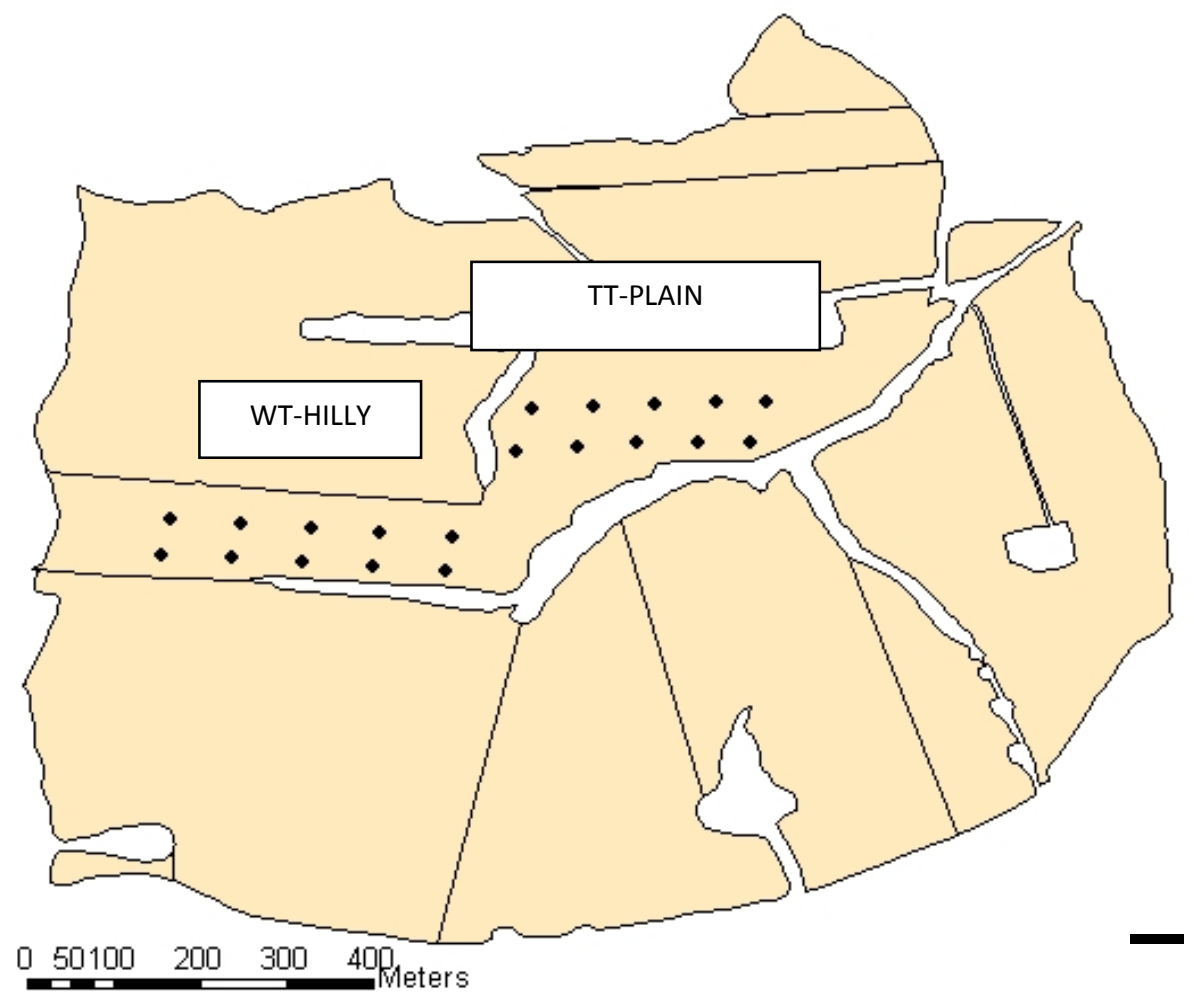

Figure 1. View of the experimental site. • GPS sampling and $\square$ treatments locations

\subsection{Soil tillage}

Conventional soil tillage was carried out in July 2011 both on hilly and plain fields on Silty Clay soil at very low water content ( 0.25 and 0.31 of the field capacity respectively), in addition direct-seeding + fertilizing was carried out in plain field in September 2011 at 0.25 of the field capacity. Same field conditions during the tests are shown in Table 1.

Plowing was carried out with the following work sites layout: 1 ) a very high power wheeled tractor (217 $\mathrm{kW}$ engine power; $9684 \mathrm{~kg}$ mass $+1600 \mathrm{~kg}$ front ballast) with reversible semi-mounted four furrow plow (2300 kg mass) operating on hilly field (WT-hilly) (Fig. 2). 2) a mean power metal tracked tractor (120 kW engine power; $14000 \mathrm{~kg}$ mass) with trailed three furrow plow (1100 kg mass), operating on plain field (TT-plain) (Fig. 3). 


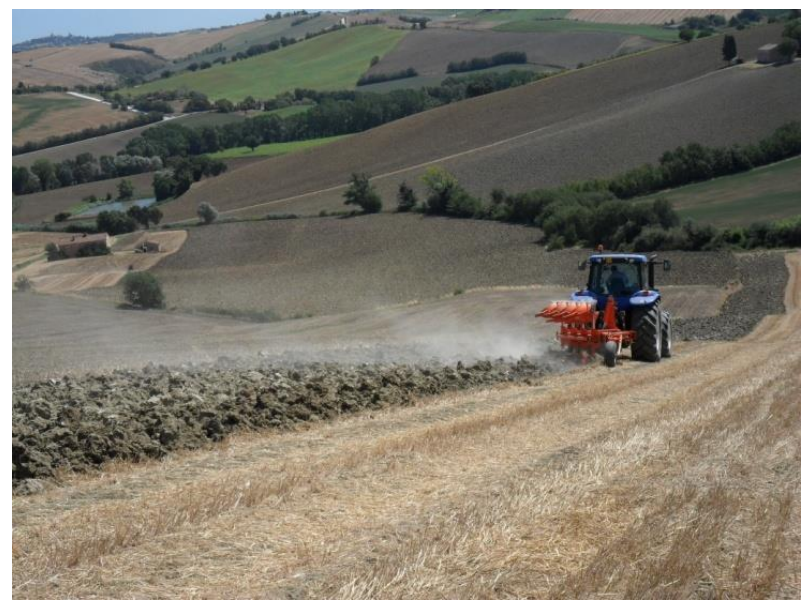

Figure 2. View of the very high power wheeled tractor with reversible semi-mounted four furrow plow

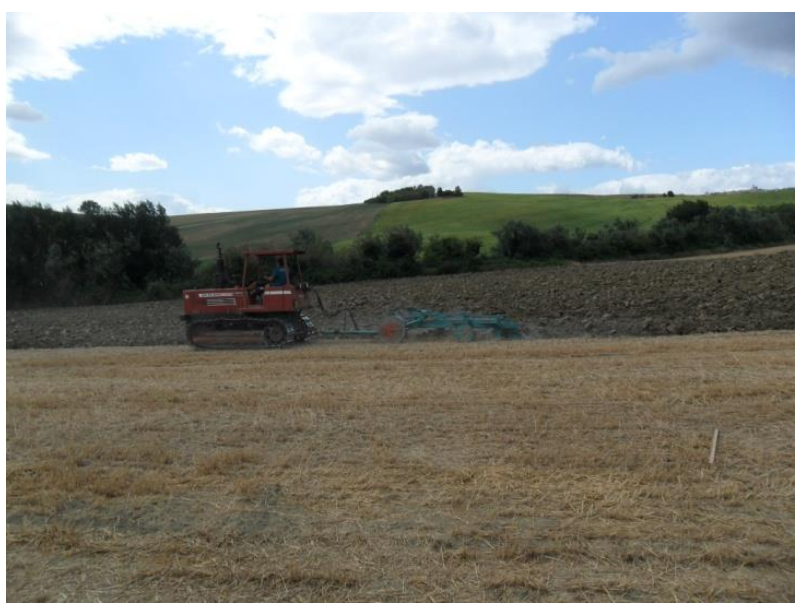

Figure 3. View of the mean power metal tracked tractor with trailed three furrow plow

Soil tillage operations were performed at very low water content, $9.8 \%$ and $11.6 \%$ for treatments WT and TT respectively.

Direct seeding was carried out by means of a very high power wheeled tractor (265 kW engine power; $18000 \mathrm{~kg}$ mass) with hydro-mechanical power transmission with trailed grain drill, a seeding unit, which consists of a seed and fertilizer box mounted above two rows of opener assemblies (for a total of 16 no till opener) operating on plain field (GD+F-plain). The front of the unit is supported by the tractor hitch, the back of the unit is supported by two wheels (Fig. 4). Direct seeding was performed at $9 \%$ water content.

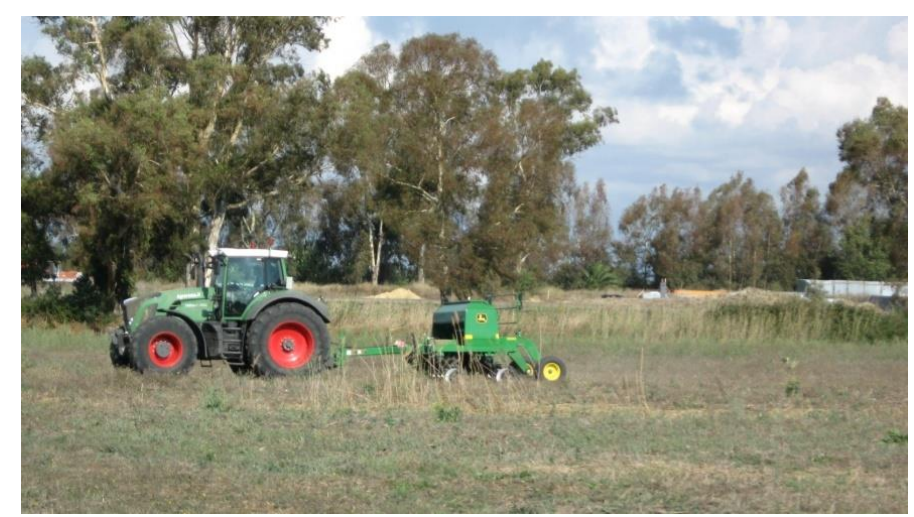

Figure 4. View of the very high power wheeled tractor with trailed grain drill 
The performance of the tractors and machineries during tillage operations were quantified through the following parameters: forward speed, tractors slip (\%), effective work capacity $\left(\right.$ ha $\left.^{-1}\right)$, measured work width $(m)$, work depth $(m)$, soil rise and roughness $(m)$, clod size distribution (\%), energy power output $(\mathrm{kW})$, hourly $\left(\mathrm{kg} \mathrm{h}^{-1}\right)$, global energy employed $\left(\mathrm{kWh} \mathrm{ha} \mathrm{a}^{-1}\right)$, fossil-fuel energy requirements $(\mathrm{GJ} / \mathrm{ha})$ and carbon dioxide emissions ( $\mathrm{kg} \mathrm{C} \mathrm{ha}^{-1}$ ) (Servadio and Bergonzoli, 2012; Marsili and Servadio, 1998). In addition field data collected has allowed to appraise the global energetic efficiency of the tractors that depends from the area (ha) covered in function of the time and from the ability of the tractor to convert the energy of combustion in useful power. As a result, two field oriented performance indicators consisting in time efficiency $\left(\mathrm{h} \mathrm{ha}^{-1}\right)$ and area specific consumption $\left(\mathrm{kg} \mathrm{ha}^{-1}\right)$ are applied (Burgun et al., 2013).

\section{Results}

\subsection{Sampling test and mapping}

Results of the sampling tests of the soil properties are shown in Table 1 and in Figs. 6 . Results of Table 1 show, both on plain and hilly fields, very high values of shear strength (over $180 \mathrm{kPa}$ ) and its CV\% and high values of dry bulk density (over $1.39 \mathrm{Mg} \mathrm{m}^{-3}$ ). Values of structural stability of soil aggregates were higher on hilly field (56\%) with respect to the plain (31.5\%). Higher values of organic matter (1.54 \%), P (11.5 ppm) and $\mathrm{Na}(3.10 \%)$ were found on plain field.

Table 1. Mean values (0-0.20 $\mathrm{m}$ depth) and coefficient of variation of some soil chemical-physical properties (June 2011)

\begin{tabular}{|c|c|c|c|c|}
\hline \multirow[t]{2}{*}{ Soil properties } & \multicolumn{2}{|c|}{ Plain } & \multicolumn{2}{|c|}{ Hilly } \\
\hline & Mean $^{a}$ & $\mathrm{CV}(\%)$ & Mean $^{a}$ & $\mathrm{CV}(\%)$ \\
\hline Sand $(g / 100 g)^{b}$ & 9.25 & 25 & 8.06 & 27.8 \\
\hline Silt $(g / 100 g)^{b}$ & 43.1 & 6.35 & 41.6 & 5.63 \\
\hline Clay $(g / 100 g)^{b}$ & 47.6 & 5.47 & 50.3 & 6.76 \\
\hline Texture $^{\mathrm{b}}$ & \multicolumn{4}{|c|}{ Silty Clay } \\
\hline Shear strength $(\mathrm{kPa})$ & 188 & 33.8 & 222 & 41.4 \\
\hline Dry bulk density ( $\mathrm{Mg} \mathrm{m}^{-3}$ ) & 1.39 & 9.79 & 1.48 & 8.50 \\
\hline Water content (\%) & 31.2 & 9.69 & 29.1 & 11.7 \\
\hline Structural stability of soil aggregates(\%) & 31.5 & & 56 & \\
\hline Field capacity (\%) & 36.7 & - & 37.9 & - \\
\hline OM (\%) & 1.54 & 14.8 & 1.30 & 14.9 \\
\hline TOC (\%) & 0.89 & 14.8 & 0.75 & 14.9 \\
\hline $\mathrm{P}(\mathrm{ppm})$ & 11.5 & 13.2 & 5.87 & 36.7 \\
\hline CEC (meq \%) & 27.5 & 4.50 & 27.2 & 4.21 \\
\hline $\mathrm{Na}(\%)$ & 3.10 & 47.6 & 1.92 & 34.6 \\
\hline
\end{tabular}

average of ten values, ${ }^{b}$ USDA classification; OM, organic matter; TOC, total organic carbon; CEC, cation exchange capacity.

The monthly mean temperatures and rainfall acquired during the overall experimentation time, are depicted in Fig. 5.

Results of the interpolation of soil properties maps performed by using the software ArcGIS and the spatial analyst tool natural neighbour are shown in Figs. 6 a, b, c and d. 


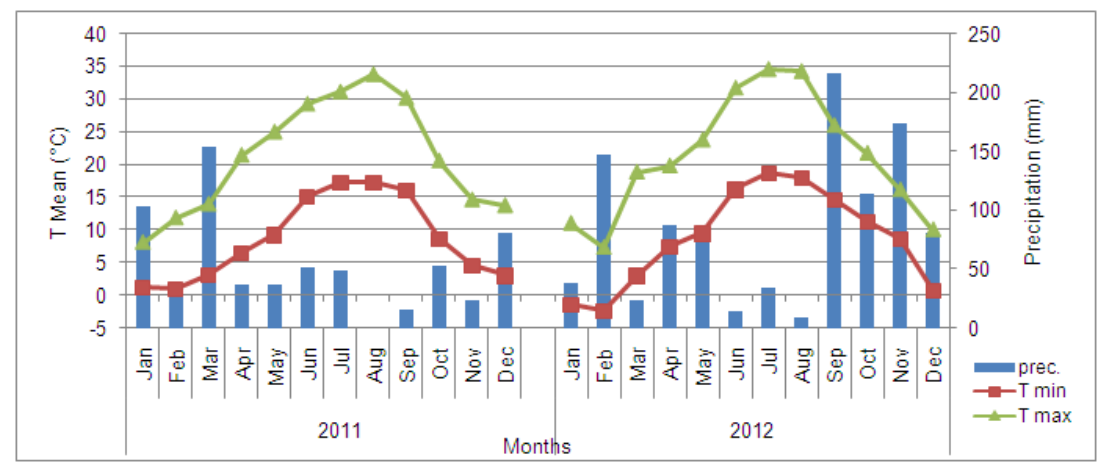

Figure 5. Monthly mean temperature and rainfall during the growing season (2011-2012)

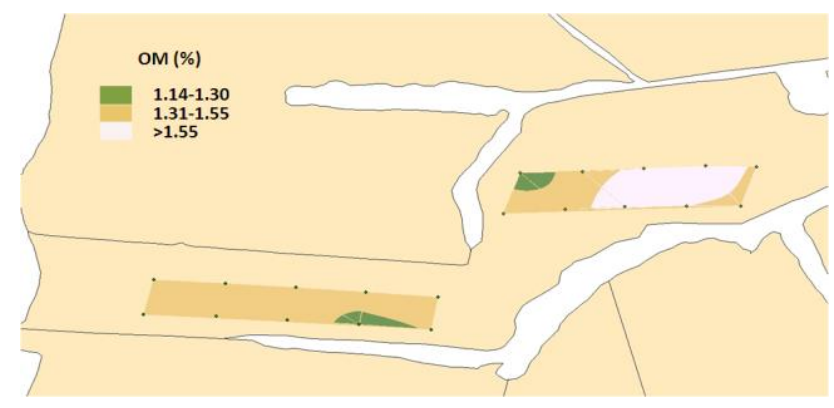

a

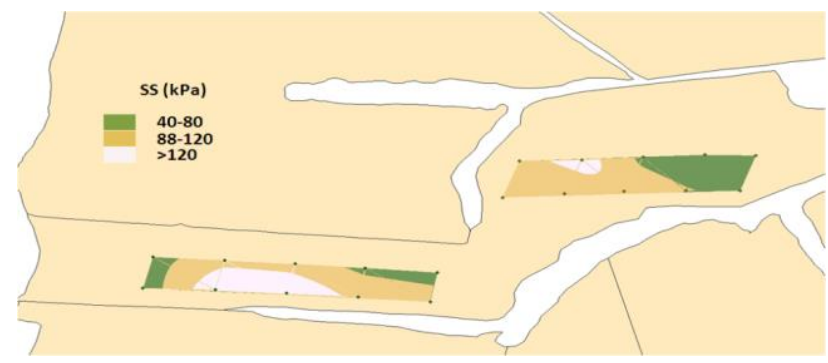

b

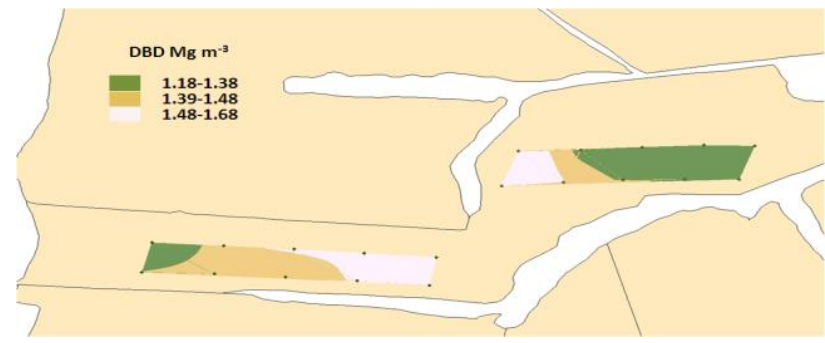

C

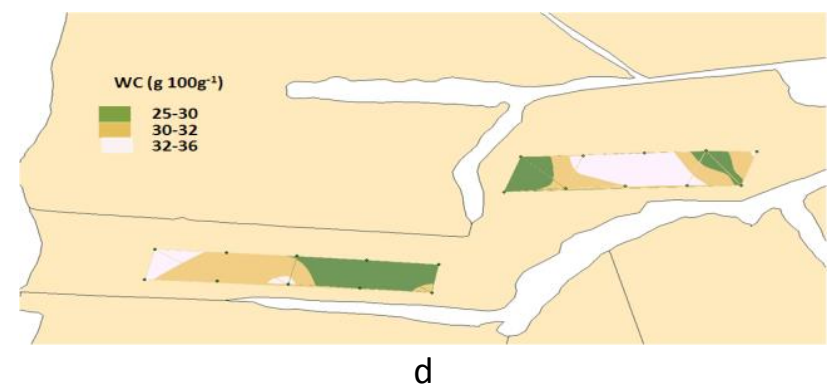

Figure 6. View of field maps of soil parameters studied: a) organic matter (\%); b) shear strength (kPa); c) dry bulk density ( $\left.\mathrm{Mg} \mathrm{m}^{-3}\right)$; d) water content (g/100g) 
From the analysis of OM (Fig. 6a), SS (Fig. 6b) and DBD (Fig. 6c) interpolated maps it emerged the presence of an homogeneous and well defined zone in the eastern part of the plain field characterized by low level of soil strength ( $\mathrm{SS}<80 \mathrm{kPa}$ and $\mathrm{DBD}<1.38 \mathrm{Mg} \mathrm{m}^{-3}$ ) and high organic matter content $(\mathrm{OM}>1.55 \%)$. Therefore this area was assessed to perform the direct seeding of common wheat. The analyzed soil parameters can be considered good indicators of the soil strength and according to the soil water content, useful to assess workability.

\subsection{Soil tillage and wheat yield}

Results of machineries performance during plowing and direct-seeding are shown in Table 2.

During CT operations carried out at $0.40 \mathrm{~m}$ work depth, both work sites layout showed good traction performance indicated from slip values always lower than $15 \%$ (Table 2). This result, besides to the low soil water content and high soil strength, were also due to the high contact area of the tracks on soil of TT-plain and to the high engine power of WT-hilly (Servadio, 2010). For wheeled tractor, hourly fuel consumption was higher $\left(47 \mathrm{~kg} \mathrm{~h}^{-1}\right)$ with respect to the tracked tractor $\left(27 \mathrm{~kg} \mathrm{~h}^{-1}\right)$; time efficiency of WThilly was enhanced from the larger work width $1.07 \mathrm{~h} \mathrm{ha}^{-1}$ with respect to the $1.78 \mathrm{~h} \mathrm{ha}^{-1}$ of the TT-plain; furthermore area specific consumption was of similar magnitude (48-50 $\left.\mathrm{kg} \mathrm{ha}^{-1}\right)$.

According with Burgun et al., (2013), this prove that the use of the wide implements enhance the time efficiency and simultaneously reduce the area specific consumption more than to use of higher forward speed. Regarding the grain-drill+fertilizing operating in plain area, due to the high forward speed and work width, time efficiency resulted $0.26 \mathrm{~h} \mathrm{ha}^{-1}$ and area specific consumption resulted $11 \mathrm{~kg} \mathrm{ha}^{-1}$.

Table 2. Performances of work sites layout during ploughing (July 2011) and direct-seeding (September 2011) and yield (June 2012)

\begin{tabular}{|c|c|c|c|}
\hline & \multicolumn{3}{|c|}{ Work sites layout } \\
\hline & TT-plain & WT-hilly & GD+F-plain \\
\hline Forward speed $\left(\mathrm{m} \mathrm{s}^{-1}\right)$ & 1.25 & 1.21 & 3.5 \\
\hline Mean rise $(\mathrm{m})$ & 0.20 & 0.30 & - \\
\hline Mean roughness (m) & 0.22 & 0.31 & - \\
\hline Measured work width (m) & 1.25 & 2.13 & 3.0 \\
\hline Measured work depth $(\mathrm{m})$ & 0.40 & 0.40 & 0.03 \\
\hline Effective work capacity $\left(\right.$ ha $h^{-1}$ ) & 0.56 & 0.93 & 3.8 \\
\hline Time efficiency $\left(\mathrm{h} \mathrm{ha}{ }^{-1}\right.$ ) & 1.78 & 1.07 & 0.26 \\
\hline \multicolumn{4}{|l|}{ Reliefs on the tractors } \\
\hline Slip (\%) & 14.1 & 6.93 & - \\
\hline Energy power output (kW) & 120 & 217 & 200 \\
\hline \multicolumn{4}{|l|}{ Fuel consumption } \\
\hline Hourly $\left(\mathrm{kg} \mathrm{h}^{-1}\right)$ & 27 & 47 & 40 \\
\hline Specific $\left(g k W h^{-1}\right)$ & 225 & 220 & 210 \\
\hline Area specific consumption $\left(\mathrm{kg} \mathrm{ha}^{-1}\right)$ & 48 & 50 & 11 \\
\hline \multicolumn{4}{|l|}{ Global energy employed } \\
\hline$\left(\mathrm{kWh} \mathrm{ha}^{-1}\right)$ & 214 & 232 & 52 \\
\hline Energy (GJ ha ${ }^{-1}$ ) & 2.24 & 2.35 & 0.52 \\
\hline $\mathrm{CO}_{2}$ emission $\left(\mathrm{kg} \mathrm{Cha}^{-1}\right)$ & 47.6 & 50.0 & 11.0 \\
\hline
\end{tabular}


Despite to the higher energy power output of the very high power wheeled tractor (WT-hilly), global energy employed were of similar magnitude of the mean power metal tracked tractor (TT-plain) because of the good time efficiency. Global energy employed was of only $52 \mathrm{kWh}^{\mathrm{h}} \mathrm{h}^{-1}$ for direct-seeding. According to Yalcin and Cakir (2006), conventional tillage method had the higher fuel consumption and the lower field efficiency as compared to the direct seeding. Fossil-fuel energy requirements from the two tractors used during plowing were of similar magnitude, in fact it was 2.24-2.35 GJ ha-1 during conventional tillage while it was significantly lower $\left(0.52 \mathrm{GJ} \mathrm{ha}^{-1}\right)$ during direct-seeding. Carbon dioxide emissions were of similar magnitude during plowing, it was $47.6-50.0 \mathrm{~kg} \mathrm{C} \mathrm{ha}^{-1}$ during conventional tillage while it was significantly lower $\left(11.0 \mathrm{~kg} \mathrm{C} \mathrm{ha}^{-1}\right)$ during direct-seeding.

Yield results of wheat (Table 3) can be ascribed to the climatic trend depicted in Figure 5 . The monthly mean temperature and rainfall recorded during the growing season (2011-2012) shown the maximum temperature values higher than $10^{\circ} \mathrm{C}$ during phase of culm growth. Furthermore the rainfall distribution from February to May ensured water requirements of the crop during the phases of culm growth and physiological maturity. Trends of precipitation and temperatures allowed a good development of the crop that did not undergo stress and recorded yield value similar to the crop under conventional tillage management. Infact wheat yield of direct seeded field resulted of similar magnitude (only $9 \%$ lower) than that recorded on fields under conventional tillage.

Table 3. Wheat yield (June 2012) and Total cost of the crop cycle

\begin{tabular}{cccc}
\hline & \multicolumn{3}{c}{ Work sites layout } \\
\hline Wheat yield $\left(\mathrm{t} \mathrm{ha}^{-1}\right)$ & TT-plain & WT-hilly & GD+F-plain \\
\hline Total Cost $(€ /$ ha $)$ & 5.6 & 5.6 & 5.1 \\
\hline
\end{tabular}

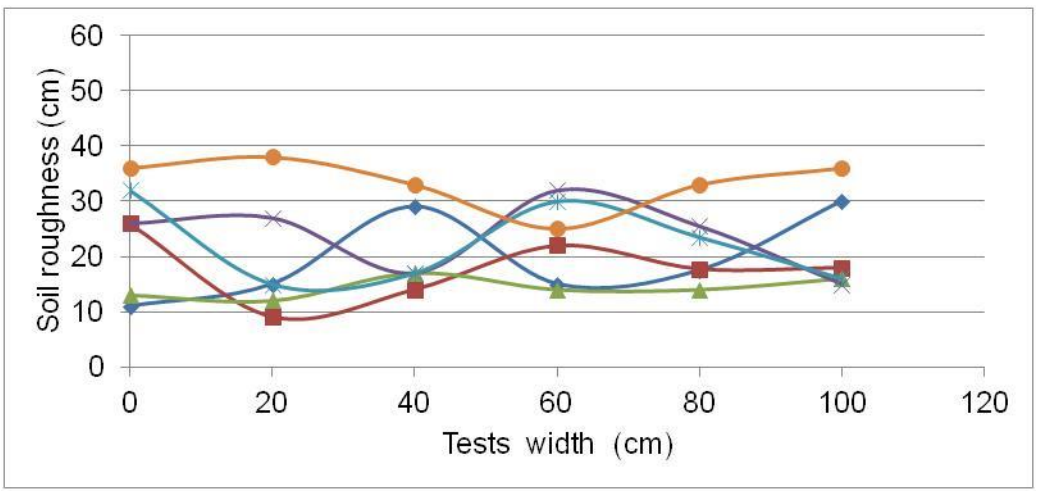

(a)

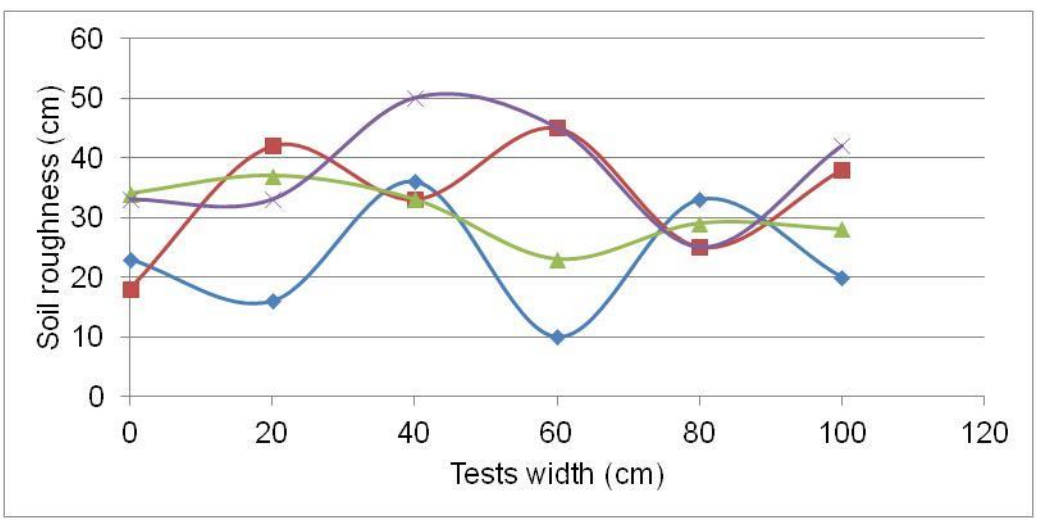

(b)

Figure 9. Soil rughness profile obtained after tillage: TT-plain (a) and WT- hilly (b). 
The total cost of the crop cycle ( $€ /$ ha) of the field under direct seeding practice resulted $16 \%$ lower of the field cultivated using conventional tillage techniques.

Results of soil roughness acquired in more sampling location, perpendicularly to the forward speed of the tractors (Figs. 9a and 9b) showed higher values for WT-hilly $(0.30 \mathrm{~m})$ with respect to the TT-plaine $(0.20 \mathrm{~m})$.

Results of clod size distribution (Fig. 10) highlighted as 15 and $20 \%$ of the clods created by tillage operations were bigger than $200 \mathrm{~mm}$.

Therefore the degree of crushing of the soil required further operation to seedbed preparation. Using a wheeled tractor of $167 \mathrm{~kW}$, p.t.o. power with mounted rotary harrow having $6.0 \mathrm{~m}$ work width and 0.74 $\mathrm{m} \mathrm{s}^{-1}$ forward speed, time efficiency was $0.62 \mathrm{~h} \mathrm{ha}^{-1}$ area specific consumption was $22 \mathrm{~kg} \mathrm{ha}^{-1}$, global energy employed was $97 \mathrm{kWh}$ ha ${ }^{-1}$ Energy was $1.04 \mathrm{GJ} \mathrm{ha}^{-1}$ and $\mathrm{CO}_{2}$ emission was $22 \mathrm{~kg} \mathrm{C} \mathrm{ha}^{-1}$. All these parameters must be added to the TT-plain and WT-hilly treatments.

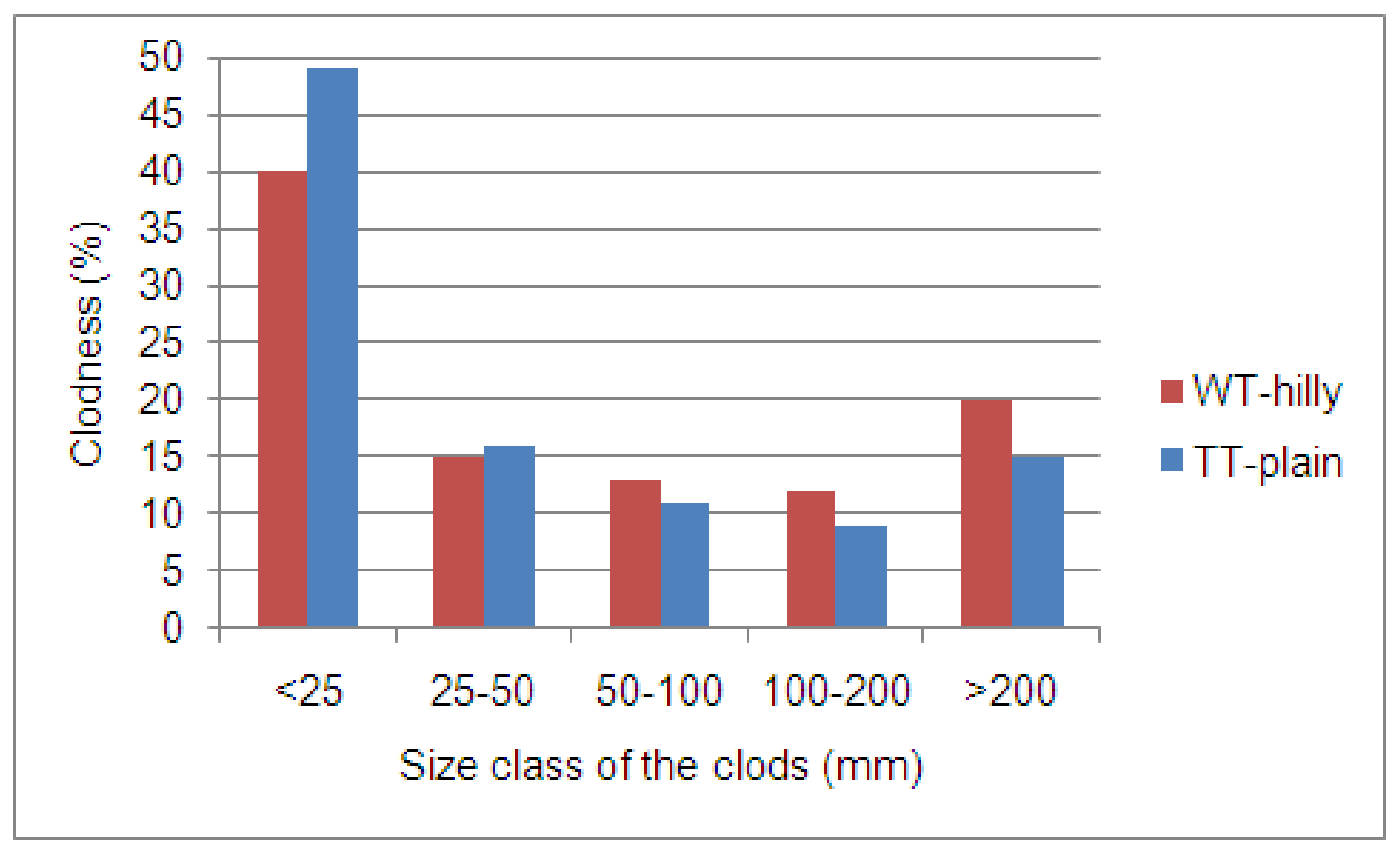

Figure 10. Clod size distribution obtained from tillage (TT-plain) and (WT-hilly)

\section{Conclusions}

As the field sampling and mapping have allowed more efficient resource management, the use of precision agricultural practices and information technologies (IT) have enhanced our understanding and the possibility to predict temporal and spatial variability of soil properties in response to management practices. For istance, some indicators of soil compaction/strength as SS, BD and OM were found and an area to perform direct seeded was selected. During $\mathrm{CT}$, good traction performance, with slip values always lower than $15 \%$, were found. Area specific consumption, global energy employed and fuel energy requirements were significantly higher during CT operation compared to direct seeding. Consequently, carbon dioxide emissions from different agricultural machineries were lower during direct-seeding. Due to the favorable climatic trend during the wheat growing season, the wheat yield of direct seeded field was of similar magnitude (only $9 \%$ lower) of that recorded on fields under conventional tillage; the total cost of the crop cycle ( $€ /$ ha) was $16 \%$ lower compared to the field cultivated under CT techniques. In conclusion, with the use of IT, hydro-mechanical power transmission and the direct seeding technique, saving in energy and in $\mathrm{CO}_{2}$ emission can be achieved and can be considered as good Climate change adaptation techniques. 


\section{Acknowledgments}

This work was carried out under the special project "Sceneries of adaptation of the Italian agriculture to the climatic changes" D.M. 8608/7303/2008 of 7.8.2008 of the Agricultural Research Council, and Italian Ministry of the Agricultural and Forestry Politics.

\section{References}

Adler P.R., Del Grosso S.J. and Parton W.J. (2007), Life-cycle assessment of net greenhouse-gas flux for bioenergy cropping systems, Ecol. Appl., 17(3), 675-691.

Allmaras R.R. and Dowdy R.H. (1985), Conservation tillage systems and their adoption in the United States, Soil Till. Res., 5(2), 197-222.

Beni C., Servadio P., Marconi S. and Neri U. (2012), Anaerobic Digestate Administration: Effect on Soil Phisical and Mechanical Behaviour in Southern Italy, Communications in Soil Science and plant analysis, 43(5): 821-834.

Burgun C., Lacour S., Delacroix A., Descombes G. and Doyen V. (2013), Computing time and fuel requirements to assess efficiency of a field work from conventional laboratory tests : application to a plowing operation, Agricultural and Food Science, 22(2), 247-261.

Chatterjee A. and R. Lal (2009), On farm assessment of tillage impact on soil carbon and associated soil quality parameters, Soil \& Tillage Research, 104(2), 270-277.

Chen S., Xia G.M., Zhao W.M., Wu F.B. and Zhang G.P. (2007), Characterization of leaf photosynthetic properties for no-tillage rice, Rice Sci., 14(4), 283-288.

Collins B.A. and Fowler D.B. (1996), Effect of soil characteristics, seeding depth, operating speed, and opener design on draft forceduring direct seeding, Soil \& Tillage Research, 39(3), 199-211.

Conant R.T., Easter M., Paustian K., Swan A. and Williams S. (2007), Impact of periodic tillage on soil C stocks: a synthesis, Soil Tillage Res., 95(1-2), 1-10.

Fowler D.B. (1995), Seeding Equipment. Winter Wheat Production Manual, Ducks Unlimited Canada, Yorkton, Sash., pp. 601-621.

Kemper W.D. (1965), Aggregate stability. Methods of Soil Analysis. Part 1. Agronomy, 9: 511-519.

Paremelee R.W., Beare M.H., Cheng W., Hendrix P.F., Rider S.J. Crossley Jr., D.A. and Coleman D.C. (1990), Earthworms and enchytraeids in conventional and notillage agroecosystems: a biocide approach to assess their role in organic matter breakdown, Biol. Fertil. Soils, 10(1), 1-10.

Puget P. and Lal R. (2005), Soil organic carbon and nitrogen in aMollisol in central Ohio as affected by tillage and land use, Soil Tillage Res., 80(1-2), 201-213.

Servadio P. (2010), Applications of empirical methods in central Italy for predicting field wheeled and tracked vehicle performance, Soil Tillage Research, 110(2), 236-242.

Servadio P. and Bergonzoli S. (2012), Tractors and machineries for conservative soil tillage in climate change conditions. International Conference on Agricultural Engineering. CIGR-AgEng 2012 Valencia, Spain, 8-12 July.

Servadio P. and Marsili A. (1998), Performance and work quality of two new machines for tilling in marginal areas. CD Proc. International Conference on Agricultural Engineering, Part 2, Paper no. 98-C-004 pp. 1-10, Oslo, Norway 24-27 August.

Servadio P., Bergonzoli S., Dell'Unto D. and Beni C. (2010), Models of soil compaction by agricultural machineries wheeling and soil qualities mapping. International Conference on Agricultural Engineering (AgEng). Towards Environmental Technologies. Clermont-Ferrand, France, 6-8 September.

Servadio P., Bergonzoli S., Dell'Unto D. and Beni C. (2011), Maize Yield and Physical-Chemical Fertility Mapping for the Management of the Soil, Journal of Information Technology in Agriculture, 4(1), 1-8.

Servadio, P., Bergonzoli, S. (2013). Spatial variability of some soil properties and wheat yield within a trafficked field. Proceedings of $9^{\text {th }}$ European Conference on Precision Agriculture. Lleida, Catalonia, Spain, July 7-11 2013

Uri N.D. (1997), Conservation tillage and input use, Environ. Geol., 29(3/4), 188-201.

VandenBygaart A.J., Yang X.M., Kay B.D. and Aspinall J.D. (2002), Variability in carbon sequestration potential in no-till soil landscapes of southern Ontario, Soil Tillage Res., 65(2), 231-241. 
Walkley A. and Black I. A. (1934). An Examination of Degtjareff Method for Determining Soil Organic Matter and a Proposed Modification of the Chromic Acid Titration Method, Soil Sci., 37,29-37.

West T.O. and Post W.M. (2002), Soil organic carbon sequestration rates by tillage and crop rotation: a global data analysis, Soil Sci. Am. J., 66(6), 1930-1946.

Wu M.G., Zhang G.H., Lin J.R. and Cheng S.H. (2005), Screening for rice germplasms with specially-elongated mesocotyl, Rice Sci., 12(3), 226-228.

Yalcin H. and Cakir E. (2006), Tillage effects and energy efficiencies of subsoiling and direct seeding in light soil on yield of second crop corn for silage in Western Turkey, Soil \& Tillage Research, 90(1-2), 250-255. 